\title{
Corynebacterium diphtheriae infection as a dermatological problem - case report and review of the literature
}

\section{Zakażenie Corynebacterium diphtheriae jako problem dermatologiczny - opis przypadku i przegląd literatury}

Paulina Cieplewicz', Marta Szymoniak-Lipska', Magdalena Jałowska', Adriana Polańska²,
Monika Bowszyc-Dmochowska', Hanna Tomczak ${ }^{3,4}$, Ryszard Żaba², Zygmunt Adamski'

'Department of Dermatology, Poznan University of Medical Sciences, Poznan, Poland

2Department of Dermatology and Venereology, Poznan University of Medical Sciences, Poznan, Poland

${ }^{3}$ Department of Genetics and Pharmaceutical Microbiology, Poznan University of Medical Sciences, Poznan, Poland

${ }^{4}$ Central Microbiological Laboratory, Heliodor Święcicki Research and Teaching Hospital, Poznan University of Medical Sciences,

Poznan, Poland

'Katedra i Klinika Dermatologii Uniwersytetu Medycznego w Poznaniu, Polska

2Zakład Dermatologii i Wenerologii Uniwersytetu Medycznego w Poznaniu, Polska

${ }^{3}$ Katedra i Zakład Genetyki i Mikrobiologii Farmaceutycznej Uniwersytetu Medycznego w Poznaniu, Polska

${ }^{4}$ Centralne Laboratorium Mikrobiologiczne Szpitala Klinicznego im. Heliodora Święcickiego Uniwersytetu Medycznego w Poznaniu, Polska

CORRESPONDING AUTHOR/ ADRES DO KORESPONDENCJI:

lek. Paulina Cieplewicz

Katedra i Klinika

Dermatologii

Uniwersytet Medycznego

w Poznaniu

ul. Przybyszewskiego 49

60-355 Poznań

e-mail: paulina.cieplewicz@ gmail.com

\begin{abstract}
We report the case of a 36-year-old male patient with alcohol dependence syndrome who was admitted to the Dermatology Unit with erythroderma of unknown aetiology persisting for approximately 2 years. A considerable degree of deformity and ulceration were noted on the patient's right hand. The patient reported that the abnormalities were due to a fall suffered the year before. The culture of material collected from the ulcer was positive for Staphylococcus aureus, Corynebacterium diphtheriae and Streptococcus dysgalactiae. Following a 10-day course of intravenous clindamycin the ulcer healed successfully. Corynebacterium diphtheriae infection should be considered in the differential diagnosis of skin ulcers, particularly in patients with alcohol dependence syndrome and general immunosuppression.
\end{abstract}

\section{STRESZCZENIE}

Przedstawiony opis przypadku dotyczy 36-letniego pacjenta, który cierpiał na zespół zależności alkoholowej. Mężczyzna został przyjęty na Oddział Dermatologii z powodu utrzymującej się od około 2 lat erytrodermii o nieznanej etiologii. W obrębie ręki prawej występowały znaczna deformacja i owrzodzenie. Według pacjenta zmiany te powstały wskutek upadku, którego doznał rok wcześniej. W posiewie $\mathrm{z}$ owrzodzenia wyhodowano Staphylococcus aureus, Corynebacterium diphtheriae oraz Streptococcus dysgalactiae. Po 10 dniach leczenia klindamycyną dożylnie nastąpiło zagojenie się owrzodzenia. Zakażenie Corynebacterium diphtheriae powinno być uwzględnione $\mathrm{w}$ diagnostyce różnicowej owrzodzeń skóry, zwłaszcza u pacjentów z zespołem zależności alkoholowej i ogólną immunosupresją. 
Key words: ulcers, erythroderma, alcohol dependence syndrome, Corynebacterium diphtheriae.

Słowa kluczowe: owrzodzenia, erytrodermia, zespół zależności alkoholowej, Corynebacterium diphtheriae.

\section{INTRODUCTION}

Diphtheria is a disease caused by bacteria of the genus Corynebacterium. Corynebacterium diphtheriae are aerobic or facultatively anaerobic, Gram-positive, nonspore-forming, and non-motile bacilli [1]. A number of species of the genus Corynebacterium are skin commensals which may also occur as opportunistic pathogens. Three species, including Corynebacterium diphtheriae (C. diphtheriae), Corynebacterium ulcerans and Corynebacterium pseudotuberculosis, have the ability to produce diphtheria toxin [2]. Before the introduction of mass vaccination programmes, diphtheria epidemics were frequent, and associated with high mortality rates. Approximately 40,000 cases of diphtheria and 3,000 deaths caused by the disease were recorded in Poland every year in the 1950s. The situation changed when a nationwide vaccination programme was started in 1954 [3]. With widespread vaccinations, diphtheria is currently a rare disease in Western European countries. However, it is alarming to note that the number of diphtheria cases has been growing in recent years, reflecting an increased migration of unvaccinated individuals [4]. Factors predisposing to the development of invasive infection with Corynebacterium diphtheriae include homelessness, intravenous drug use, alcohol abuse, and diabetes. Corynebacterium diphtheriae infections are more prevalent in men than in women [5].

A typical clinical manifestation of Corynebacterium diphtheriae infection is the presence of painful non-healing ulcers covered with grey-whitish pseudomembranes. Diphtheria can be classified into faucial, cutaneous and wound-related types. Faucial diphtheria is characterized by general malaise, fever, massive lymphadenopathy ("Neron's neck"), severe throat pain, dyspnoea, and dysphagia. Oropharyngeal examination reveals whitish-grey pseudomembranes that are difficult to remove. This form of the disease is transmitted by droplet infection. Cutaneous diphtheria presents as painful, non-healing, chronic ulcers at the inoculation site, often accompanied by the formation of greyish-whitish pseudomembranes similar to those seen in faucial diphtheria. Cutaneous diphtheria is also manifested by erythema and local skin oedema. Cutaneous diphtheria can be divided into primary (caused by hetero-inoculation with the pathogen) and second-

\section{WPROWADZENIE}

Błonica to choroba wywołana przez bakterie z rodzaju Corynebacterium. Maczugowce błonicy to tlenowe lub fakultatywnie beztlenowe Gram-dodatnie laseczki, które nie wytwarzają przetrwalników i nie mają zdolności ruchu [1]. Wiele gatunków z rodzaju Corynebacterium to komensale skórne, które mogą występować także jako patogeny oportunistyczne. Trzy gatunki - Corynebacterium diphtherie (C. diphteriae), Corynebacterium ulcerans i Corynebacterium pseudotuberculosis - mają zdolność wytwarzania toksyny błoniczej [2]. Do czasu wprowadzenia masowych szczepień błonica była przyczyną częstych epidemii z wysoką śmiertelnością. W latach 50. XX wieku w Polsce rejestrowano ok. 40000 zachorowań i 3000 zgonów rocznie. Sytuacja zmieniła się, gdy w 1954 roku wprowadzono powszechne szczepienia przeciwko błonicy [3]. Ze względu na powszechność szczepień błonica jest obecnie rzadko obserwowana w krajach Europy Zachodniej. Niepokojący jest jednak fakt, że wraz ze wzrostem migracji osób nieszczepionych w ostatnich latach stwierdza się coraz więcej zachorowań [4]. Czynnikami predysponującymi do rozwoju inwazyjnego zakażenia maczugowcem błonicy są: bezdomność, przyjmowanie narkotyków dożylnie, alkoholizm i cukrzyca. Zakażeniom tym częściej ulegają mężczyźni niż kobiety [5].

Typowym objawem klinicznym zakażenia maczugowcem błonicy są bolesne, niegojące się owrzodzenia pokryte szaro-białawymi błonami rzekomymi. Wyróżnia się błonicę gardła, błonicę skórną oraz błonicę przyranną. Błonica gardła charakteryzuje się złym stanem ogólnym, gorączką, masywnym powiększeniem węzłów chłonnych szyi (tzw. szyją Nerona), silnym bólem gardła, dusznością, problemami z połykaniem. W badaniu jamy ustnej i gardła stwierdza się trudne do usunięcia białawo-szare błony rzekome. Transmisja tej postaci zakażenia odbywa się drogą kropelkową. Skórna postać błonicy cechuje się obecnością bolesnych, niegojących się, przewlekłych owrzodzeń w miejscu inokulacji, często z szarawo-białawymi błonami rzekomymi, podobnymi do tych, które występują w błonicy gardła. W błonicy skórnej stwierdza się również rumień i miejscowy obrzęk skóry. Błonicę skórną można podzielić na postać pier- 
ary developing as a result of auto-inoculation secondary to prior (e.g. faucial) diphtheria infection. The last type, wound diphtheria, represents superinfection of preexisting skin lesions, and occurs more commonly in immuno-incompetent individuals [6].

\section{OBJECTIVE}

The aims of the study are to present a case of C. diphtheriae infection of the skin, and review the literature on this subject.

\section{CASE REPORT}

A 36-year-old male patient with erythroderma was admitted to the Clinical Dermatology Unit for diagnostics and therapy. By taking the patient's history, it was established that at the time of admission erythroderma had persisted for over 2 years. In addition, the patient had suffered from alcohol dependence syndrome for about a dozen years. The man reported that he had been vaccinated against diphtheria under the Mandatory Vaccination Programme. He also stated that he had not left Poland in the recent period, and had not been in contact with any individuals staying in countries with high rates of endemic diphtheria. Physical examination demonstrated erythema accompanied by exfoliation affecting the entire cutaneous surface (figs. $1 \mathrm{~A}, \mathrm{~B}$ ).

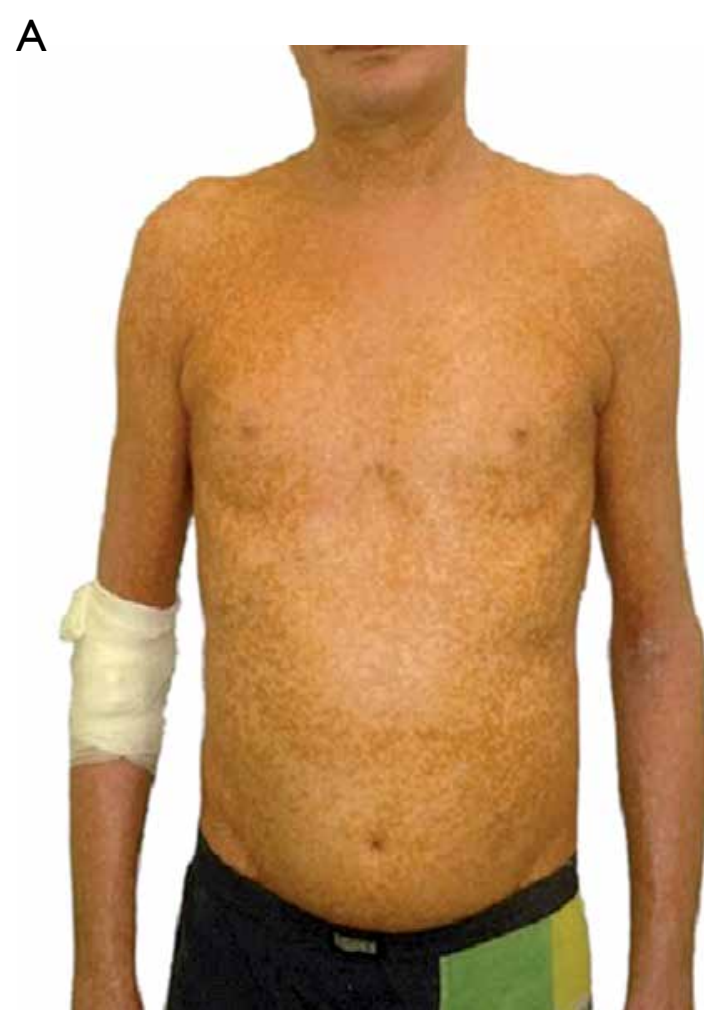

Figure I. A, B - Erythroderma

Rycina I. A, B - Erytrodermia wotną, wywołaną przez heteroinokulację patogenem, i wtórną, która rozwija się w wyniku autoinokulacji w przebiegu wcześniejszej błonicy (np. gardłowej). Błonica przyranna jest $\mathrm{z}$ kolei nadkażeniem istniejących wcześniej zmian skórnych i występuje częściej u osób immunoniekompetentnych [6].

\section{CEL PRACY}

Celem pracy jest przedstawienie przypadku zakażenia C. diphtheriae w obrębie skóry oraz przegląd danych $\mathrm{z}$ piśmiennictwa na ten temat.

\section{OPIS PRZYPADKU}

Mężczyzna 36-letni został przyjęty na Oddział Kliniczny Dermatologii z powodu erytrodermii w celu rozpoznania i leczenia. Na podstawie wywiadu ustalono, że erytrodermia utrzymywała się od ponad 2 lat. Pacjent od kilkunastu lat cierpiał na zespół zależności alkoholowej. Podawał, że był w przeszłości szczepiony przeciwko błonicy zgodnie z programem szczepień obowiązkowych. Negował wyjazdy poza granice Polski w ostatnim czasie oraz kontakty z osobami, które przebywały w krajach endemicznego występowania błonicy. W badaniu przedmiotowym na skórze całej powierzchni ciała stwierdzono rumień z towarzyszącym złuszczaniem (ryc. 1 A, B).

B

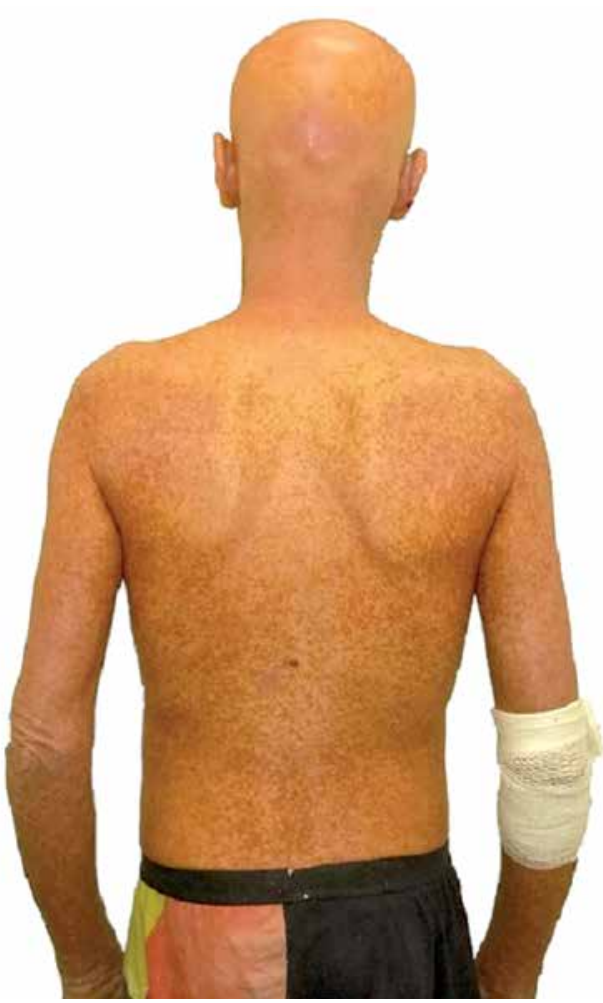


A marked deformity caused by a fall suffered by the patient about 1 year previously and an ulcer were observed on the patient's right hand. The ulcer had a diameter of approximately $4 \mathrm{~cm}$, and was painful, deeply penetrating, with a visible tendon at the bottom, surrounded by an erythematous rim (fig. 2).

A notable finding was the enlargement of cervical, supra- and infraclavicular, axillary, and inguinal lymph nodes. The skin lesions were accompanied by pruritus.

A range of diagnostic examinations was ordered on the day of hospital admission. A biopsy specimen was taken from the pathologically altered skin on the thigh for histological evaluation, and microbiological culture of material sampled from the ulcer on the right hand was performed. In addition, the patient underwent radiographic examination of the right hand. Topical corticosteroids and antihistamine drugs were also introduced on account of generalized inflammation of the skin. Before the results of microbiological tests (identification and antibiogram) were available, empirical antibiotic therapy with intravenous ceftriaxone at a dose of $2 \mathrm{~g}$ / day was administered. The culture of the material obtained from the ulcer was positive for Staphylococcus ureus (S. aureus), C. diphtheriae and Streptococcus dysgalactiae (S. dysgalactiae). The $C$. diphtheriae culture material was sent to the National Institute of Public Health - National Institute of Hygiene in Warsaw for verification and evaluation of toxin production. The examined strain was not found to have a toxin-producing ability. When the microbiological test results were available, the patient had a consultation with a specialist in infectious diseases. Based on the specialist's recommendations, the man was isolated and received targeted antibiotic therapy based on the antibiogram - clindamycin at a dose of $600 \mathrm{mg}$, twice daily, administered intravenously over a period of 10 days. Diphtheria antitoxin was not administered, as the patient did not
W obrębie ręki prawej widoczne były znaczna deformacja związana z upadkiem, którego pacjent doznał rok wcześniej, oraz owrzodzenie. Owrzodzenie o średnicy ok. $4 \mathrm{~cm}$ było bolesne, drążące głęboko, $\mathrm{z}$ widocznym ścięgnem $\mathrm{w}$ dnie, otoczone rumieniową obwódką (ryc. 2).

Uwagę zwracały powiększone węzły chłonne szyjne, nad-i podobojczykowe, pachowe i pachwinowe. Zmianom skórnym towarzyszył świąd.

W dniu przyjęcia do szpitala zlecono u chorego liczne badania diagnostyczne, w tym pobranie wycinka ze zmienionej chorobowo skóry uda do badania histologicznego, posiew mikrobiologiczny z owrzodzenia w obrębie ręki prawej oraz badanie RTG dłoni prawej. Ze względu na uogólniony stan zapalny skóry wdrożono terapię glikokortykosteroidami miejscowymi oraz leczenie przeciwhistaminowe. Do czasu otrzymania wyniku badania mikrobiologicznego (identyfikacji wraz z antybiogramem) zastosowano antybiotykoterapię empiryczną - ceftriakson w dawce $2 \mathrm{~g}$ / dobę dożylnie. W posiewie z owrzodzenia wyhodowano Staphylococcus aureus (S. aureus), C. diphtheriae oraz Streptococcus dysgalactiae (S. dysgalactiae). Materiał z hodowli $C$. diptheriae został przekazany do Narodowego Instytutu Zdrowia Publicznego - Państwowego Zakładu Higieny w Warszawie w celu potwierdzenia i oceny pod kątem wytwarzania toksyny. Badania nie potwierdziły zdolności do wytwarzania toksyny przez badany szczep. Po otrzymaniu wyniku mikrobiologicznego przypadek skonsultowano ze specjalistą chorób zakaźnych. Według zalecenia mężczyznę odizolowano i zastosowano antybiotykoterapię celowaną zgodną z antybiogramem - klindamycynę 2 razy dziennie $\mathrm{w}$ dawce $600 \mathrm{mg}$ dożylnie przez 10 dni. Ze względu na brak objawów ogólnych i niewytwarzanie toksyny błoniczej przez wyizolowany szczep nie podano antytoksyny błoniczej.

W dniu przyjęcia do szpitala obserwowano podwyższone parametry stanu zapalnego (OB $52 \mathrm{~mm}$,

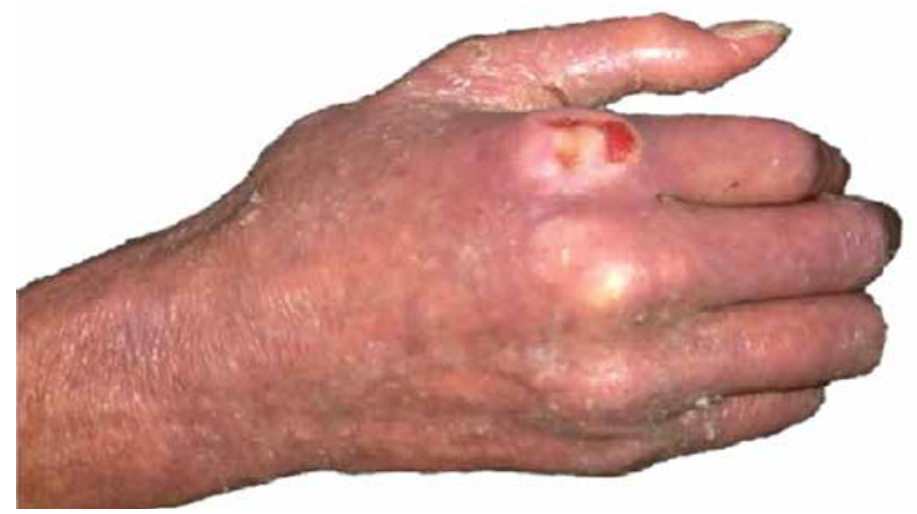

Figure 2. Ulcer with a diameter of approximately $4 \mathrm{~cm}$, deeply penetrating, with tendon visible at the bottom, surrounded by erythematous rim

Rycina 2. Owrzodzenie o średnicy ok. 4 cm, drążące głęboko, z widocznym ścięgnem w dnie, otoczone rumieniową obwódką 
present with any systemic symptoms, and the isolated strain did not produce diphtheria toxin.

On the day of admission, the patient's inflammatory parameters were elevated (ESR $52 \mathrm{~mm}, \mathrm{CRP}$ $33.3 \mathrm{mg} / \mathrm{l}$ ), and his CBC with differential demonstrated leukocytosis $\left(\right.$ WBC $\left.31.88 \times 10^{3} / \mu 1\right)$ with lymphocytosis $\left(11.53 \times 10^{3} / \mu \mathrm{l}\right)$ as well as atypical lymphocytes. The phenotypic distribution of lymphocyte subpopulations by peripheral blood flow cytometry revealed a very high proportion of CD3+ $\mathrm{T}$ cells $(94 \%)$, with a predominance of CD8+ (52\%) over CD $4+$ cells $(40 \%)$, presence of $48 \%$ of activated T cells (CD3+/DR+), and very low proportions of B and NK cells. On this basis, a suspicion of neoplastic T-cell proliferation was raised. Histopathological examination of a skin specimen taken from the thigh revealed moderately dense infiltrates composed of lymphoid cells, located subepidermally and remaining in contact with the epidermis (fig. 3). The diagnostic workup was expanded to include an immunohistochemical examination which, however, provided no evidence for the diagnosis of atypical B- and T-cell proliferation.

During hospitalization, the patient was assessed by a haematologist who ordered further haematological diagnostic observation on an outpatient basis. Serological tests for syphilis, and HIV, HCV and $\mathrm{HBV}$, were negative. Radiographic examination of the right hand revealed destruction and deformation of articular surfaces of the metacarpophalangeal joint, with mutual displacement of the base of the proximal phalanx and the second metacarpal bone of the second digit. A consultation with an orthopaedist was conducted, and elective arthrodesis was recommended.

The treatment produced an improvement in the dermatological condition and complete healing of the
CRP 33,3 mg/l), a w morfologii z rozmazem leukocytoze $\left(\right.$ WBC $\left.31,88 \times 10^{3} / \mu \mathrm{l}\right)$ z limfocytozą $(11,53 \times$ $\left.10^{3} / \mu \mathrm{l}\right)$ oraz atypowe limfocyty. W cytometrii przepływowej krwi obwodowej w rozkładzie fenotypowym subpopulacji limfocytów zwracał uwagę bardzo wysoki odsetek komórek T CD3+ (94\%), z przewagą CD8+ (52\%) nad CD4+ (40\%), z obecnością $48 \%$ komórek T aktywowanych (CD3+/DR+) oraz bardzo niski odsetek komórek B i NK. Na tej podstawie wysunięto podejrzenie rozrostu nowotworowego z komórek T. W badaniu histopatologicznym wycinka skóry uda obecne były pozostające w łączności z naskórkiem i zlokalizowane pod naskórkiem średnio gęste nacieki złożone $\mathrm{z}$ komórek limfoidalnych (ryc. 3). Diagnostykę poszerzono o badanie immunohistochemiczne, w którym nie stwierdzono podstaw do rozpoznania atypowej proliferacji z komórek B i T.

W czasie hospitalizacji pacjenta konsultowano hematologicznie i uzyskano zalecenia dalszej diagnostyki hematologicznej w trybie ambulatoryjnym. Wykonano badania serologiczne $w$ kierunku kiły oraz HIV, HCV i HBV - wyniki były ujemne. W badaniu RTG ręki prawej stwierdzono destrukcję i deformację powierzchni stawowych stawu śródręczno-paliczkowego pierwszego z przesunięciem względem siebie podstawy paliczka bliższego i II kości śródręcza palca II. Pacjenta konsultowano ortopedycznie - zalecono artrodezę w trybie planowym.

Wskutek zastosowanego leczenia uzyskano poprawę stanu dermatologicznego i całkowite zagojenie się owrzodzenia, w obrębie śródręcza ręki prawej widoczny był niewielki krwisty strup (ryc. 4 A, B).

\section{OMÓWIENIE}

Błonica ze względu na wysoki wskaźnik szczepień jest chorobą rzadko występującą w krajach wyso-

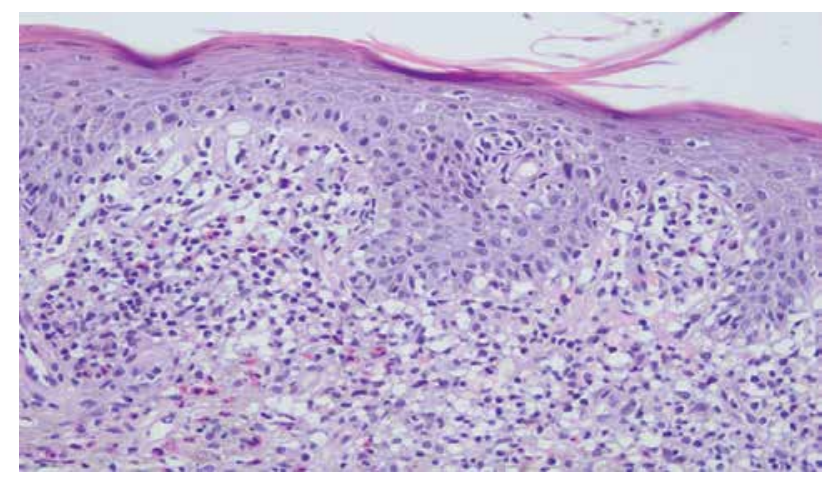

Figure 3. Histopathological examination of a biopsy specimen taken from the skin of the thigh with visible symptoms of erythroderma. Just below the epidermis, a lymphoid infiltrate with an admixture of eosinophils, epidermotropism seen in isolated cells of the infiltrate. The density of the infiltrate may give rise to a suspicion of T-cell lymphoma. Haematoxylin and eosin staining, magnification $200 \times$

Rycina 3. Badanie histopatologiczne wycinka pobranego ze skóry uda z objawami erytrodermii. Tuż pod naskórkiem naciek limfoidalny z domieszką eozynofilów, epidermotropizm pojedynczych komórek nacieku. Gęstość nacieku może budzić podejrzenie chłoniaka T-komórkowego. Barwienie hematoksyliną i eozyną, powiększenie $200 \times$ 

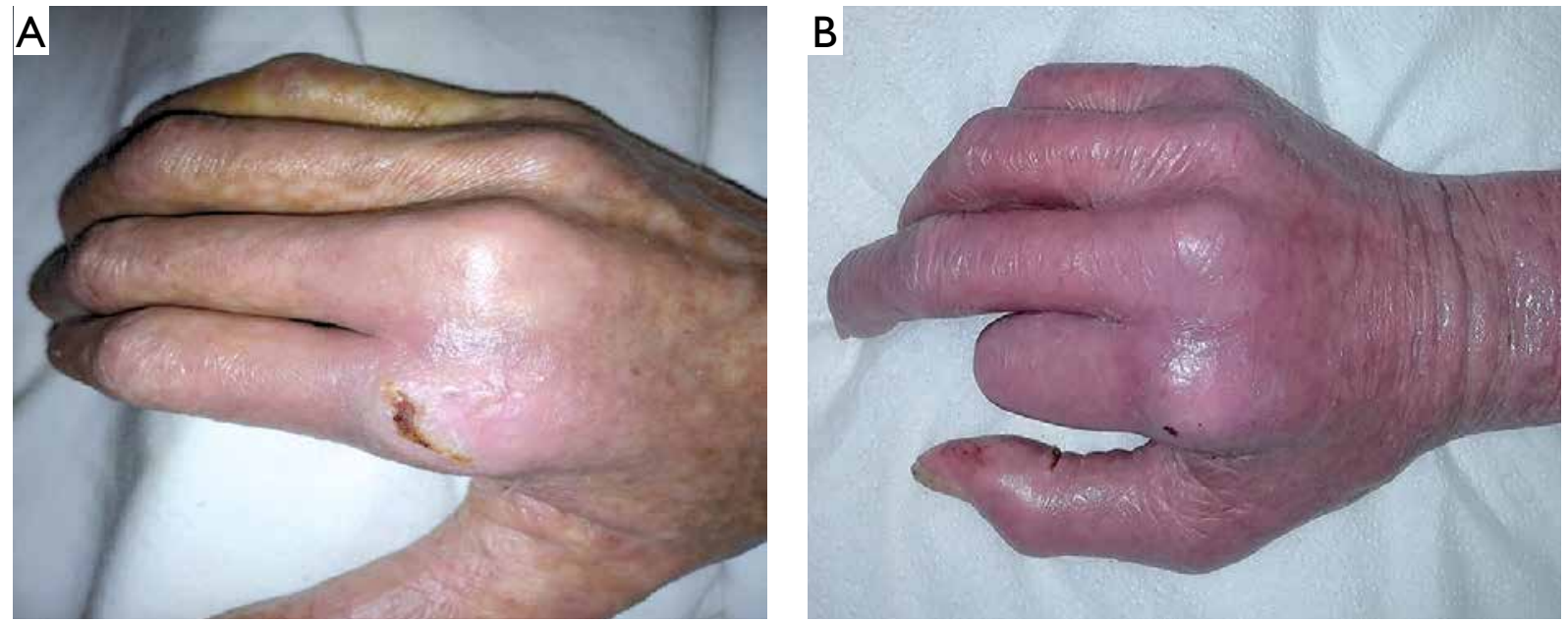

Figure 4. Skin condition in the previously ulcerated area: A - on the day of discharge, $\mathbf{B}-3$ months after the end of treatment Rycina 4. Stan skóry w miejscu wcześniejszego owrzodzenia: A - w dniu wypisu, B - po 3 miesiącach od zakończenia leczenia

ulcer. A small haemorrhagic scab was noted in the metacarpal area of the right hand (figs. 4 A, B).

\section{DISCUSSION}

On account of high vaccination rates diphtheria is an infrequent disease in developed countries. However, with the increase of migration and the recent wave of refugees arriving in Europe, new cases of the disease are observed [4]. The last case of diphtheria in Poland reported to the World Health Organization (WHO) occurred in 2000, but 6 new cases of the disease were recorded in the United Kingdom in 2017 [7].

Diphtheria toxoid was first developed in 1921, however it was not widely used until the 1930s. There is no vaccine with isolated diphtheria toxoid. Available products contain diphtheria toxoid in combination with tetanus toxoid or with tetanus toxoid and pertussis vaccine. The efficacy of the toxoid to induce appropriate immunization is estimated at $97 \%$. According to applicable recommendations, booster doses of diphtheria toxoid should be given every 10 years [8].

Vaccination against diphtheria is included in the Polish Mandatory Vaccination Programme. An updated Programme is announced every year as a Communication from the Chief Sanitary Inspector, and published in the Polish Journal of Laws [9]. Appropriate immunization, however, has no effect on $C$. diphtheriae colonization. All confirmed carriers should be treated [8]. Vaccination produces immunity only against inactivated diphtheria toxin, referred to as diphtheria toxoid, but without eliminating the risk of infection with C. diphtheriae [10]. Corynebacterium diphtheriae acquire the ability to produce the toxin after infection with a lysogenic phage carrying the tox gene [11]. Exotoxin-producing strains of C. diphtheriae have a particular potential to induce systemic ko rozwiniętych. Jednak wraz ze wzrostem migracji i ostatnią falą uchodźców w Europie obserwowane są nowe zachorowania [4]. Ostatni przypadek błonicy w Polsce zgłoszony do Światowej Organizacji Zdrowia (World Health Organization - WHO) wystąpił w 2000 roku, podczas gdy 6 przypadków nowych zachorowań odnotowano w 2017 roku w Wielkiej Brytanii [7]. Anatoksyna błonicza została wyprodukowana w 1921 roku, lecz nie była w powszechnym użyciu do lat 30. XX wieku. Nie istnieje szczepionka z izolowaną anatoksyną błoniczą. W dostępnych produktach występuje ona $\mathrm{z}$ toksoidem tężcowym lub toksoidem tężcowym i szczepieniem przeciwko krztuścowi. Skuteczność anatoksyny w wywoływaniu odpowiedniej immunizacji wynosi 97\%. Zaleca się, aby dawki przypominające szczepienia zawierającego anatoksynę błoniczą powtarzane były raz na 10 lat [8]

Szczepienie przeciw błonicy w Polsce znajduje się w programie szczepień obowiązkowych. Program ten jest co roku publikowany jako komunikat Głównego Inspektora Sanitarnego i ogłaszany w Dzienniku Ustaw [9]. Odpowiednia immunizacja nie wpływa jednak na występowanie zjawiska kolonizacji przez C. diphtheriae. Każde potwierdzone nosicielstwo powinno być leczone [8]. W następstwie szczepienia odporność nabywana jest wyłącznie przeciwko inaktywowanej toksynie błonicznej, tzw. anatoksynie błoniczej, nie zostaje jednak wyeliminowana możliwość zakażenia C. diphtheriae [10]. Maczugowce błonicy nabywają zdolność do produkcji toksyny po infekcji fagiem lizogenicznym przenoszącym gen tox [11]. Szczepy C. diphtheriae wytwarzające egzotoksyny mają szczególny potencjał wywoływania ogólnoustrojowych objawów zakażenia oraz powikłań, $\mathrm{w}$ tym zapalenia mięśnia sercowego i neuropatii obwodowej [12]. Infekcje skórne maczugowcem błonicy są opisywane jako przewlekłe, niegojące się owrzo- 
manifestations of infection, and produce complications including myocarditis and peripheral neuropathy [12]. Cutaneous infections with C. diphtheriae are described as chronic non-healing ulcers secondary to an injury or an underlying primary skin disease. Skin lesions are usually superinfected with non-toxigenic strains [13].

Individuals infected with $C$. diphtheriae are, in a large proportion, intravenous drug users, people abusing alcohol, the unemployed and homeless [10]. Diphtheria cases reported in the medical literature are associated with poor socioeconomic conditions. Inadequate hygiene and low socioeconomic status, as well as densely populated households, are factors conducive to $C$. diphtheriae colonization [14]. Also, wound diphtheria is more commonly diagnosed in immuno-incompetent individuals [6].

Studies conducted in Vancouver in 1998-2007 in the city population identified 33 cases of cutaneous diphtheria infection. The most prevalent coexisting disease was hepatitis C $(63.4 \%)$, and the socioeconomic status of patients with wound diphtheria was similar. The patients came from a poor city district (Downtown Eastside - 90.9\%). Furthermore, as many as $52 \%$ of infected patients were HIV carriers [15]. The skin is the more common site of $C$. diphtheriae infection than the throat. The cutaneous form of infection appears to be more contagious than diphtheria of the upper respiratory tract. Also, the former type more frequently progresses to the state of carriage than the latter [16, 17].

The diagnosis of diphtheria relies on the results of bacterial culture, identification and confirmation of toxin production [11]. The differential diagnosis of non-healing ulcers should also take into account ecthyma, leishmaniasis, atypical mycobacterial infections, pyoderma gangrenosum, and deep mycosis [4]. Cutaneous lesions in wound diphtheria are also frequently superinfected with other bacteria, including S. aureus or Streptococcus spp. [4], which was also the case in the patient presented in this report.

The treatment of diphtheria, regardless of the form of the disease, is based on macrolide antibiotics (erythromycin, azithromycin or clarithromycin), or benzylpenicillins administered intravenously or orally for 14 days [18]. Patients should be isolated, and if in doubt about previous vaccinations, they should receive complete vaccination against diphtheria. The administration of diphtheria antitoxin is indicated in cases involving infection with toxigenic strains. The antitoxin binds to circulating diphtheria toxin and neutralizes it, however without affecting previously tissue-bound toxin. As a result, delayed administration of diphtheria antitoxin is associated with an increased mortality. The administration of diphtheria antitoxin in cases of dzenia powstałe w wyniku urazu lub na podłożu pierwotnej choroby skóry. Zmiany skórne są nadkażone najczęściej szczepami nietoksynogennymi [13].

Duża część zakażonych C. diphtheriae to osoby stosujące narkotyki dożylnie, nadużywające alkoholu, bezrobotni oraz bezdomni [10]. Opisywane w piśmiennictwie medycznym przypadki błonicy są związane ze złymi warunkami socjoekonomicznymi. Brak higieny oraz niski status socjoekonomiczny, przeludnienie $\mathrm{w}$ gospodarstwach domowych sprzyjają utrzymywaniu się kolonizacji maczugowcami [14]. Błonica przyranna jest rozpoznawana częściej u osób immunoniekompetentnych [6].

W badaniach przeprowadzonych w Vancouver w latach 1998-2007 wśród populacji miejskiej stwierdzono 33 przypadki zakażenia błoniczego skóry. Najczęstszą chorobą współistniejącą było zapalenie wątroby typu C $(63,4 \%)$, a warunki socjoekonomiczne $\mathrm{u}$ chorych na błonicę przyranną były zbliżone. Pacjenci pochodzili z biednej dzielnicy (Downtown Eastside - 90,9\%). Ponadto aż 52\% z zakażonych było nosicielami wirusa HIV [15]. Miejscem infekcji C. diphtheriae jest częściej skóra niż gardło. Skórna postać zakażenia wydaje się bardziej zakaźna niż błonica górnych dróg oddechowych i częściej niż błonica dróg oddechowych przechodzi w stan nosicielstwa [16, 17].

Diagnoza błonicy opiera się na hodowli bakteryjnej, identyfikacji oraz potwierdzeniu produkcji toksyn [11]. W diagnostyce różnicowej niegojących się owrzodzeń należy uwzględnić niesztowicę, leiszmaniozę, zakażenia atypowymi mykobakteriami, piodermię zgorzelinową, grzybicę głęboką [4]. Zmiany skórne w błonicy przyrannej są często nadkażone innymi bakteriami, w tym S. aureus lub Streptococcus spp. [4], co miało miejsce również u opisywanego pacjenta.

W leczeniu błonicy, niezależnie od jej postaci, stosuje się antybiotyki z grupy makrolidów (erytromycynę, azytromycynę lub klarytromycynę) bądź benzylopenicyliny $\mathrm{w}$ formie dożylnej lub doustnej przez 14 dni [18]. Należy izolować chorego, a w razie wątpliwości co do wykonywanych w przeszłości szczepień przeprowadzić pełne szczepienie przeciwko błonicy. Podawanie antytoksyny błoniczej jest wskazane w przypadku zakażenia szczepami toksynotwórczymi. Antytoksyna wiąże się z krążącą toksyną błoniczą i neutralizuje ją, nie wpływa na toksynę związaną wcześniej w tkankach, dlatego opóźnienie podawania antytoksyny błoniczej związane jest ze zwiększoną śmiertelnością. Podawanie antytoksyny błoniczej w przypadku błonicy dotyczącej skóry bez objawów ogólnoustrojowych nie jest wskazane [18].

Wydaje się, że opisywany przypadek może stanowić przykład błonicy przyrannej (zakażenie rany pourazowej z występowaniem niegojącego się owrzodzenia), jednak ze względu na współwystępowanie zespołu zależności alkoholowej i trudności z zebra- 
cutaneous diphtheria without systemic symptoms is not recommended [18].

It appears that the reported case may be an example of wound diphtheria (infection of a traumatic wound involving a non-healing ulcer), however because of coexisting alcohol dependence syndrome and difficulty in collecting patient history, cutaneous diphtheria cannot be definitely ruled out. It is also important to note that the primary reasons for hospitalization in the described case - which were erythroderma and suspected haematologic disease - can be risk factors for $C$. diphtheriae infection in the reported patient (according to the literature data on C. diphtheriae infections in immuno-incompetent individuals).

Before obtaining culture results with antibiogram the reported patient was treated with empirical antibiotic therapy (ceftriaxone $2 \mathrm{~g}$ i.v./day). As soon as the culture results with antibiogram were available, a consultation was held with a specialist in infectious diseases. Clindamycin treatment, initiated in accordance with the culture results, led to the complete healing of the ulcer. Symptomatic therapy of erythroderma failed to bring about complete resolution of lesions.

\section{CONCLUSIONS}

The case is reported because of the uncommon occurrence of $C$. diphtheriae infections in patients with chronic skin ulcers. Corynebacterium diphtheriae infection should be considered in the differential diagnosis of cutaneous ulcers, particularly in patients with alcohol dependence syndrome and general immunosuppression [19]. Early diagnosis and reporting of diphtheria are crucial for ensuring effective public health protection.

\section{CONFLICT OF INTEREST}

The authors declare no conflict of interest. niem wywiadu ostatecznie nie można wykluczyć błonicy skórnej. Na uwagę zasługuje ponadto fakt, że pierwotna przyczyna hospitalizacji u przedstawionego pacjenta, jaką była erytrodermia i podejrzenie choroby hematologicznej, może stanowić czynnik ryzyka wystąpienia zakażenia $C$. diphtheriae w opisanym przypadku (zgodnie $\mathrm{z}$ danymi z piśmiennictwa na temat zakażeń $C$. diphtheriae u osób immunoniekompetentnych).

U przedstawionego pacjenta do czasu uzyskania wyniku posiewu z antybiogramem stosowano antybiotykoterapię empiryczną (ceftriakson w dawce $2 \mathrm{~g} /$ dobę dożylnie). Po uzyskaniu wyniku posiewu i antybiogramu poproszono o konsultację specjalisty chorób zakaźnych. Leczenie klindamycyną (zgodnie z posiewem) spowodowało całkowite zagojenie się owrzodzenia. Leczenie objawowe w odniesieniu do erytrodermii nie skutkowało całkowitym ustąpieniem zmian.

\section{WNIOSKI}

Powyższy przypadek przedstawiono ze względu na rzadkie występowanie zakażeń $C$. diphtheriae u pacjentów z przewlekłymi owrzodzeniami skóry. Zakażenie $C$. diphtheriae powinno być uwzględnione w diagnostyce różnicowej owrzodzeń skóry, zwłaszcza u pacjentów z zespołem zależności alkoholowej i ogólną immunosupresją [19]. Wczesna diagnoza i zgłaszanie przypadków błonicy mają istotne znaczenie dla efektywnej ochrony w kontekście zdrowia publicznego.

\section{KONFLIKT INTERESÓW}

Autorzy nie zgłaszają konfliktu interesów.

\section{References}

Piśmiennictwo

1. Zasada A.: Występowanie i chorobotwórczość dla człowieka potencjalnie toksynotwórczych maczugowców Corynebacterium diphtherie, Corynebacterium ulcerans i Corynebacterium pseudotuberculosis. Post Mikrobiol 2013, 52, 201-209.

2. Kraszewska A.K., Szewczyk E.M.: Postępy w taksonomii i metodach identyfikacji izolowanych od ludzi bakterii z rodzaju Corynebacterium. Post Mikrobiol 2011, 50, 155-167.

3. Augustynowicz E., Zasada A.: Szczepionka przeciw błonicy. Available at: http://szczepienia.pzh.gov.pl/szczepionki/blonica/; December 2018

4. Kolios A.G.A., Cozzio A., Zinkernagel A.S., French L.E., Kündig T.M.: Cutaneous Corynebacterium infection presenting with disseminated skin nodules and ulceration. Case Rep Dermatol 2017, 9, 8-12.

5. Zasada A.A., Baczewska-Rej M., Wardak S.: An increase in non-toxigenic Corynebacterium diphtheria infections in Poland - molecular epidemiology and antimicrobial susceptibility of strains isolated from past outbreaks and those currently circulating in Poland. Int J Infect Dis 2010, 14, e907-e912.

6. Rappold L.C., Vogelgsang L., Klein S., Bode K., Enk A.H., Haenssle H.A.: Primary cutaneous diphtheria: management, diagnostic work up, and treatment as exemplified by a rare case report. J Dtsch Dermatol Ges 2016, 14, 734-736.

7. WHO Diphtheria reported cases.: Available at: http://apps.who.int/immunization_monitoring/globalsummary/timeseries/tsincidencediphtheria.html; 2.01.2018. 
8. Immunology and Vaccine-Preventable Diseases - Pink Book - Tetanus. Available at: https://www.cdc.gov/vaccines/pubs/ pinkbook/downloads/dip.pdf; 5.01.2018.

9. Komunikat Głównego Inspektora Sanitarnego z dnia 31 października 2017 r. w sprawie Programu Szczepień Ochronnych na rok 2018. https://gis.gov.pl/wp-content/uploads/2018/04/Program-Szczepień Ochronnych-na-rok-2018.pdf.

10. Zasada A.A., Zaleska M., Podlasin R.B., Seferynska I.: The first case of septicemia due to nontoxigenic Corynebacterium diphtheriae in Poland: case report. Ann Clin Microbiol Antimicrob 2005, 4, 8.

11. Holmes R.K.: Biology and molecular epidemiology of diphtheria toxin and the tox gene. J Infect Dis 2000, 181 Suppl 1, 156-167.

12. Moore L.S.P., Leslie A., Meltzer M., Sandison A., Efstratiou A., Sriskandan S.: Corynebacterium ulcerans cutaneous diphtheria. Lancet Infect Dis 2015, 15, 1100-1107.

13. Belsey M.A.: Isolation of Corynebacterium diphtheriae in the environment of skin carriers. Am J Epidemiol 1970, 91, 294-299.

14. Gruner E., Opravil M., Altwegg M., von Graevenitz A.: Nontoxigenic Corynebacterium diphtheria isolated from intravenous drug users. Clin Infect Dis 1994, 18, 94-96.

15. Lowe C.F., Bernard K.A., Romney M.G.: Cutaneous diphtheria in the urban poor population of Vancouver, British Columbia, Canada: a 10-year review. J Clin Microbiol 2011, 49, 2664-2666.

16. Belsey M.A., LeBlanc D.R.: Skin infections and the epidemiology of diphtheria: acquisition and persistence of C. diphtheria infections. Am J Epidemiol 1975, 102, 179-184.

17. Public Health Service.: C. diphtheria infections most hazardous in skin. Public Health Rep 1969, 84, 3.

18. Cohen C., de Gouveia L., du Plessis M., McCarthy K., Mlisana K., Moodley Ntshoe G., et al.: Diphtheria: NICD recommendations for diagnosis, management and public health response. Available at: www.nicd.ac.za/wp-content/uploads/2017/03/ NICD-guidelines_diphtheria_v3_28-May-2018.pdf; December 2018.

19. Bonnet J.M., Begg N.T.: Control of diphtheria: guidance for consultants in communicable disease control. World Health Organization. Commun Dis Public Health 1999, 2, 242-249.

Received: 18.01 .2019

Accepted: 28.02.2019

Otrzymano: $18.01 .2019 \mathrm{r}$

Zaakceptowano: 28.02.2019 r.

\section{How to cite this article}

Cieplewicz P., Szymoniak-Lipska M., Jałowska M., Polańska A., Bowszyc-Dmochowska M., Tomczak H., Żaba R., Adamski Z. Corynebacterium diphtheriae infection as a dermatological problem - case report and review of the literature. Dermatol Rev/Przegl Dermatol 2019, 106, 25-33. DOI: https://doi.org/10.5114/dr.2019.82988. 